\title{
Is Fair Trade Really a Solution to Create Fairness in Agricultural Trade? - Case in Indonesia
}

\author{
Ermita Yusida and Juwita P. R. Suwondo, Member, IACSIT
}

\begin{abstract}
Fair trade is a dream of an ideal trade. Fair trade originated to protect all economic actors' producer, trader, and consumer. This issue escalated when classical failed to explain why many countries (especially developing countries) suffered a $g$ reat loss due to international trade, particularly in the agricultural sector. Classical theories tend to stand in the favor of Developed Countries, so that free trade was focused more on who wins and who loses. Agriculture has unique characteristics that can not be equaled with any other sector. In fact agricultural free trade policies often do not lead to fair trade. Farmers as producers actually do not have a bargaining power. However, fair trade is not a mere dream, as it can be actualized by improving the institutional system, especially in Developing Countries.
\end{abstract}

Index Term-Fair trade, agriculture, farmers, middlemen, Indonesia.

\section{INTRODUCTION}

Fair trade can never stop being an issue in agricultural sector in a country. Some [1]-[4] nailed the research hard to the ground of fair trade theory and its evolution through the ages. It faces challenges to go along the path of the economic relationship and create cooperation that is justifiable. Marston [5] had worded it perfectly: justice for all. The equality side of the word includes fair price, quality of the product, and fair coordination. It protects both the supply and the demand side. There was a statement that certification in a fair trade system is crucially needed, and it helps the details covered as every system has its loopholes. Fair trade evolves through the time, and couple decades prove enough of the changing experience institutionally [6].

Some research conducted in developing and emerging countries already found that certification does play its part on maintaining what real fair trade can be like. African farmers are the focus on the researches [7], [8] in which both discovered results that oppose one another. Beccheti and Constantino supported the application of fair trade in agricultural sector, with findings indicating the well-being of the farmers in Kenya. Factors determined this good news are such as price premium, price stabilization, and in-kind benefits, including technical assistance plus an additional one not directly included in formal criteria (product diversification). While on the other side Elder, et al found that fair trade certification does not perform as well as it's predicted, as neither the certified farmers or non-certified

Manuscript received December, 13, 2013; revised March 31, 2014

The authors are with the National Pingtung University of Science and Technology, Pingtung 91201, Taiwan (e-mail: yusi_chic@yahoo.com, the.ondowuzz@gmail.com). ones depend heavily on the technical matters to any Fair Trade Organization.

Either way, the main idea of fair trade lies in the theory that by buying such products, the consumer can both satisfy the demand for benefits and, at the same time improve the well-being of poor producers elsewhere in the world [9]. More than just a fair transaction, it develops more like a value in economic activities, for both the consumer and the producer as well. What's interesting is the role of the distributor and the government in all this. Just like mentioned before [2], distributors and industrialists seek the advantages of fair trade without taking on all its costs and obligations, and they attempt to avoid supervision by and negotiation with fair trade organizations. And as for the government, its job is focused mainly to build and legislate new food protections against the wishes of powerful actors in the market.

This leads to the main question in this paper: is it at all possible to create fair trade system in agricultural sector in a country? If so, are the proofs enough to back up this statement? And if not, why? While the opposing groups remain to make the line longer with doing similar research to prove its perspective, the supporting side of research also works just as harder. This paper tries to explain why it can't and why it might can, both based on previous researches, and study the case in Indonesia and finally find out whether it is actually able or not conducting a fair and healthy economic transactions, and what should be done in order to make it happen.

\section{Fair Trade Is a Solution of Future Trade}

Conventional trade economy known as comparative advantages have been promised benefits for anyone who does free trade. Symbiotic mutualism, that's the classic trade theory jargon. However, confidence in this classical view became extinct because many countries, especially developing country suffered losses due to free trade, especially for their agricultural sectors. Farmers are always in the marginalized not improved but rather deteriorated [10]. Until finally comes the fair Trade. WFTO [11] as a pioneer organization showed that fair trade is fundamentally, a response to the failure of conventional trade to deliver sustainable livelihoods and development opportunities to people in the poorest countries of the world; this is evidenced by the two billion of our fellow citizens who, despite working extremely hard, survive on less than us $\$ 2$ per day. Poverty and hardship limit people's choices while market forces tend to further marginalise and exclude them. Fair Trade Advocacy [12] also notice, over 4,000 
small-scale producer groups in more than 50 developing countries participate in fair trade supply chains. More than five million people in Africa, Latin America, and Asia benefit from fair trade.

The Fair Trade movement believes that trade can be a fundamental driver of poverty reduction and greater sustainable development, but only if it is managed for that purpose, with greater equity and transparency than is currently the norm. We believe that the marginalised and disadvantaged can develop the capacity to take more control over their work and their lives if they are better organised, resourced and supported, and can secure access to mainstream markets under fair trading conditions. All Fair Trade products originate from producers and workers committed to Fair Trade principles. However, in the subsequent supply chain, Fair Trade products are traded and marketed through two distinct but complementary channels:

1) The integrated supply chain route whereby products are imported and/or distributed by organisations that have Fair Trade at the core of their mission and activities, using it as a development tool to support disadvantaged producers and to reduce poverty, and combine their marketing with awareness-raising and campaigning.

2) The product certification route whereby products complying with international standards are certified indicating that they have been produced, traded, processed and packaged in accordance with the specific requirements of those international standards.

The famous implementation of fair trade is standardization. This certificate through many studies that reveal that fair trade successfully applied. The strategy of placing products with the label of guarantee on the market has resulted in spectacular growth of "fair" trade: in Europe alone sales were 250 million dollars in 1995 [13]. All of the products with the equity label have registered, in a greater or lesser measure, advances in the different countries where they are sold. In Denmark, for example, sales of equity coffee have grown $20 \%$ yearly [14]. In Great Britain, Cafedirect grew by 55\% in 1998 alone 7. In Europe, the label enjoys widespread recognition among consumers $(57 \%$ in Switzerland, $80 \%$ in the Netherlands, $36 \%$ in Denmark), who attribute positive qualities to it. New countries, new importers, and new distributors are constantly being incorporated into the initiative.

Public institutions are increasingly frequent consumers of products with the equity label, beginning with the European Parliament, where fair coffee is consumed. Numerous press articles report on the initiative and its aims, always in a positive light. In other words, "fair" products are making way in the buying habits of the wide public in countries of the North. For the small producers of the South, fair trade accounts for six million dollars that were transferred to them between 1996 and 1999 [14]. Through the periode, the advantage of fair trade is very significant. Fig. 1, showed growth sales products after join with fair trade.

Based on Fig. 1, total retail value of Fair Trade is likely to increase significantly. During the period 20001-2009, growth reached 87 percent. But, in 2008 had declined due to the financial crisis that would affect the stability of the International currency. These developments indicate that
Fair Trade has been successfully realized. The results, showed that the system justice in the world trade can be created and certainly not just a dream anymore.

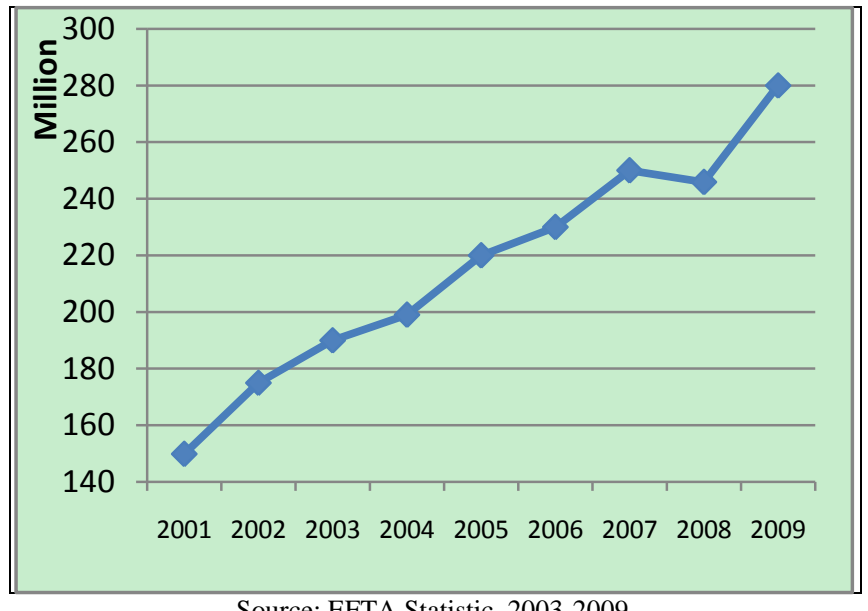

Fig. 1. Total fair trade retail value (in euros) by all EFTA members jointly.

The impact of fair trade can be seen from the export sales bigger than local sales. In 2009, WFTO notice that 64 percent of sales are export sales, of the rest 36 percent are local sales (Fig. 2). This indicates that Fair trade could be encouraging exports. With the export increase, hope farmers income will be increase.

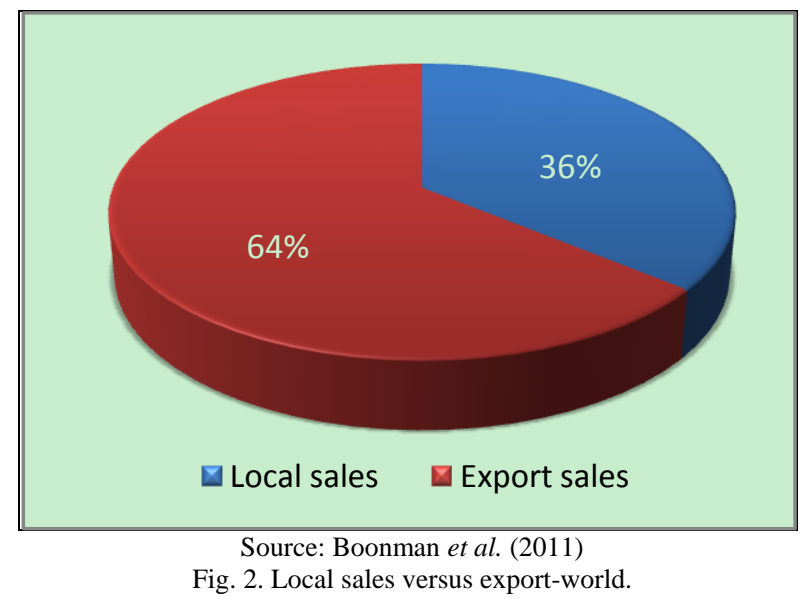

Of the total sales are still dominant, namely non-food by 78 percent and 22 percent of food products. Although this has not been the dominant food products, but there is a difference that is quite sharp, wherein the food product using the FLO label is much larger than FLO food without labels, respectively 18 percent and 4 percent [15]. This means that food products berlebel FLO will be many consumers demand. This indicates that the product will also be able to develop agriculture if agriculture is listed in fair trade by FLO label.

Seeing the success of fair trade and fair trade objectives, one of which is to reduce poverty and to realize fair trade, it appears that the various associations of farmers began to open and get interested to participate in fair trade, which proved by the success of farmers' associations in Kenya. Findings indicate that FT works in directions which seem to directly contribute to the improvement of farmers' wellbeing, but also that one aspect (support for human capital investment) may be improved. This Fair trade can be 
realized if determined by the application of certain criteria, specifically price premium, price stabilization, and in-kind benefits, including technical assistance plus an additional one not directly included in formal criteria (product diversification). This combination reduces farmers' risks and seems to generate positive effects on price, living condition satisfaction, and other relevant socio-economic indicators.

The advantage of fair trade is also keenly felt by coffee producers in Costa Rica. After joining the fair trade, coffee price in Costa Rica was relatively stable, even on the research period (1980-1989) coffee price often reached under the minimum level of price that approved by the fair trade organization. This is indicated that fair trade with the floor pricing can help to minimalize producer risk. The success can happened because the association role, they keep countinuosly to campaign and awareness rises.

In the case of the observed Kenyan farmers are that fair trade affiliation seems to be associated with superior capabilities, economic and social well-being, but also that more can be done on the human capital side. This case indicated that institutional one of important role for improvement the farmers. Institutional non only farmers assotiation, but also government. Government structure changes, corporate concentration, oversupply, interchangeable commodity grade beans, and low farm gate prices characterize the crisis in conventional coffee markets. In contrast, certified Fair Trade and organic are two alternative forms of specialty coffee trade and production that may offer opportunities for small-scale producers. A research team surveyed 228 Northern Nicaragua farmers to measure the impact of sales on organic and Fair Trade markets. The results suggest that participation in organic and Fair Trade networks reduces farmers' livelihood vulnerability.

So, fair trade is one of best solutions to reduce social unequality and farmers risk level. This can happen because there are supporting factors, which consist of:

1) Actively efficient farmers' institution

2) Good farmers' education

3) Fully supporting government either in promotional campaign or financial assistance

4) Highly aware consumers

Thus the problems of farmers that always on the weak side, consumers that often unsure of the quality of the product, and middlemen that devilishly scheme and control the market prices would be able to be resolved. In order to create a fair trade, institutional development, education, and awareness are the paramount golden keys [16]-[18].

\section{FAIR TRADE Is Not AlWAys A SOLUTION}

Fair Trade currently enjoys popularity as the trend right now is very much different than decade ago. According to a 2013 GlobeScan survey that carried out in 17 countries, nearly 6 in 10 consumers have seen the fair trade mark on the products that goes on sale, and of those, 9 out of 10 trust it. The sales continues to grow strongly across most markets. We can see from Table I that Germany has broken the half billion mark, with growth of 33 percent in the last two years. And South Africa continues its strong upward trend, more than tripling its Fairtrade sales for the third year running [19]. This indicates a very obvious fact that people keep becoming familiar with fair trade.

TABLE I: ESTIMATED RETAIL SALES By COUNTRY

\begin{tabular}{|c|c|c|c|}
\hline Country & 2011 (in $€$ ) & 2012 (in $€$ ) & $\begin{array}{c}\text { Growth } \\
(\%)\end{array}$ \\
\hline Canada & $199,768,996$ & $197,277,194$ & -1 \\
\hline Czech Republic & $2,859,432$ & $2,744,524$ & $\mathrm{n} / \mathrm{a}$ \\
\hline Denmark & $74,908,637$ & $71,836,714$ & -4 \\
\hline Finland & $102,673,112$ & $152,263,629$ & 48 \\
\hline France & $315,416,709$ & $345,829,378$ & 10 \\
\hline Germany & $400,544,747$ & $533,062,796$ & 33 \\
\hline Hongkong & - & 422,803 & $\mathrm{n} / \mathrm{a}$ \\
\hline Italy & $57,542,552$ & $65,435,059$ & 14 \\
\hline Japan & $59,327,333$ & $71,419,147$ & 17 \\
\hline South Africa & $7,273,254$ & $22,263,619$ & 220 \\
\hline Spain & $20,026,046$ & $22,274,635$ & 11 \\
\hline UK & $1,531,539,170$ & $1,904,891,092$ & 16 \\
\hline USA & - & $53,116,771$ & $\mathrm{n} / \mathrm{a}$ \\
\hline Rest of The World & $74,741,866$ & $47,487,290$ & $\mathrm{n} / \mathrm{a}$ \\
\hline Sub total & $3,344,748,492$ & $4,049,213,986$ & 21 \\
\hline Fair trade USA & $1,030,670,695$ & - & $\mathrm{n} / \mathrm{a}$ \\
\hline Grand Total & $4,375,419,187$ & $4,049,213,986$ & -4 \\
\hline
\end{tabular}

Nonetheless, no system goes without some challenges. Parvathi and Waibel [20] are among ones that stand against not the idea of it, but the chances that are not relatively big under several conditions. These following are what fair trade nowadays is lacking of [20]-[23]:

1) Technology

2) Information access

3) Transaction costs

4) Local conditions

5) Government policies

First, it's about technicality, which is technology (no pun intended). Most developing countries don't have the same kind of one used daily in developed countries. The perfect example would be the comparison between Latin America (Mexico) and United Kingdom (UK). For the same kind of good, say, coffee, the technology is different and for developing countries, it means only one word: cost. Coffeecutting technology absorb cost a lot, and at extreme cases, coffee farms have even been abandoned throughout the region as farmers and their families move to urban areas to settle in squatter communities or to begin their migration to El Norte, the USA.

There are countries that can make it big and fully embrace the definition of fair trade, but some just fall before even spell the world. The cause of this failure can be varied from technology and information access, until the very fundamental factor like government policy. Of course this does not mean that fair trade can not be applied in all countries. While it indeed can increase the quality of the product as well as the benefit received by producers (farmers), the essential thing that can not be left out as the potential threat is the lacking of efficiency of the 
management.

Regarding this problem of ineffiency and market failure, several authors therefore suggest restructuring current Fair Trade schemes to create greater producer benefits. Fair Trade should, as its founding principles state, be redesigned as a support to the development of commercial capacities. One of the examples of a perception held in researcher's mind is that the networks and capacities built by the different fair trade organizations could help small-scale farmers get larger shares of the high-value export markets that fair trade tries to compete in. However until now, research is still have not found whether or not, and how, fair trade could support producers in developing countries in keeping up with high quality requirements and gaining market shares on high value-added segments that already suffer from saturation [22]-[24].

Assumption of how everyone shares the same amount of information (perfect information) can not be applied to see how fair trade actually works. Information access is a very crucial thing, because in the case of Turkey, the asymmetric information is down to the level that the people are not even aware of fair trade existence. Even at 2012, it's not a wellknown concept yet [25]. The awareness is pretty low if compared to UK, which is $35 \%$ against $70 \%$, which is double the percentage. What makes fair trade still can not grow as big as the already-successful countries, undoubtedly is ignorance.

Transaction cost, such as transfer vehicle cost, does matter. Though according to Parvathi and Waibel, it can be reduced by using an established cooperative. Bottom line, fair trade organization and the representatives of the farmers. But the fact sometimes bites back the theory hard. In Rwanda, neither cooperative organization nor fair trade certification is associated with perceived trust among community members (the farmers). What even more surprising is that both cooperative organization and fair trade certification hold a significant negative association with trust in cooperative board members.

Local condition is the only unavoidable factor than can not be reduced for. When it's about quality, it can be upgraded and certified cooperatives can be accounted for by reduced uncertainty and enhanced incentives provided to producers. But when we talk about local condition, if fair trade standards are unrealistic for local conditions, their effectiveness will also suffer a decline since they cannot be implemented. Gonzales and Nigh [26] did a research of Mexico farmers that leads to the conclusion that the imposition of formal rules of organization without concern for the underlying processes of social learning and the building of social and human capital is bound to fail to create effective institutions capable of implementing longlasting development solutions. In short, any fair trade organization must not take the local condition (the people, the land, the climate) for granted for the success of the system and learn to enhance what has already built there.

Still in Rwanda, the vertical relationships between the state and the local level (bridging social capital) enabled government authorities to use political and manipulative powers to undermine the horizontal associations between farmers of different ethnic groups (bonding social capital) of the agricultural cooperatives. The case may not be the same in all countries. Arnould conducted a research in three countries: Nicaragua, Peru, and Guatemala. All showed a mixed result, though the conclusion reached was that fair trade is not the solution for third-world poverty. And that happened not because of the government, but the enthusiasm for innovations, willingness to learn, or other alternative explanations for the results. Good government policy can lead to plantation-focused regulation and thus brings benefit to farmers as well as the consumers.

Another thing that government tends to overlook is the supply chain for the smallholders. They can make it up by creating and supporting fairer supply chains for their smallholders and help build the capacity of producer organisations to capture more value from their production. After that comes the problem with the export promotion of a country, which can be enhanced by including within their export promotion strategies measures to support initiatives such as Fairtrade (not to confuse with Fair Trade), which enable smallholders to capture more value, over the long term, in international markets. The last time government should do is to focus on enabling smallholders to capture more value from their products.

Market power is one of the most important market failures that happens in agricultural market. Market failure in this case means the inability to achieve effiency in allocation. Notice that once again, the "efficient" word comes above the surface. This efficiency relates to the success of the market. From the argument of Sexton and Rogers about market structure, several typical characteristics of raw agricultural commodity markets should make the analysis of imperfect competition in these markets routine. These characteristics include the bulky and perishable nature of agricultural products, producers' geographic immobility, and the sunk cost aspect of specialized crops [27].

Lastly, what drives interest in researching fair trade in agricultural sector is finding that out of all products, one that can be considered successful is coffee. Almost every optimist papers used coffee as the ground data, and it indeed becomes the dominant product in agricultural fair trade. That can be happened because of the "coffee happening", in, mostly, USA. Of all things that farmers are doing hard at planting and harvesting, coffee is one the few things needed everyday, sometimes even more than twice a day. This is also the part of the "expensive coffee" standard embedded in people's mind, that has anything to do with a brand Starbucks. This implies that not all food crops suits the fair trade in consumer's taste in application.

\section{AgricUlture In INDONESIA}

Agriculture in Indonesia becomes one of the best because of the land endowment in the country. It is proved by the fact that Indonesia honored as one of the Top 5 of best food crops-producing countries in ASIA during 2008-2012 [28]. The Indonesia agricultural sector remain large, comprising 14 percent of the country's aggregate Gross Domestic product (GDP) during 2005-2012 [29]. It means that agriculture sector is one the economic key strength in Indonesia.

Moreover, agriculture is also one of the biggest employment providers. The evidence showed through the 
immense amount of people currently working in agricultural sector. In 2012 the most sector that has the most workers is agriculture, in 35.1 percent, and secondly who work in trade, hotel and restorant is 20.9 percent, and thirdly, who work in Community, Social, and Personal Services is 15.4 percent [29]. This indicated that the role of agriculture very important and it is a source of income.

However, ironically the largest poor population lies on the agriculture sector. During the 1999-2008 period, almost the whole poor population are people works in agriculture sector with average 54.5 percent. The second place goes to service sector at 27 percent, while poverty that caused by unemployment follows at the third in 9.45 percent, and the last place is industry sector in 9.05 percent (Fig. 3). This indicates that income in the agricultural sector is incredibly smaller than the other industries.

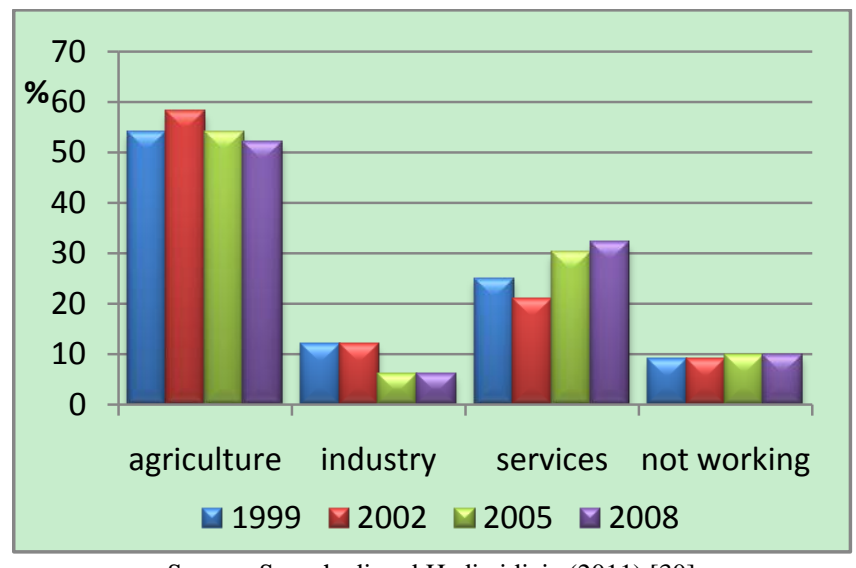

Source: Suryahadi and Hadiwidjaja (2011) [30]

Fig. 3. Sectoral Share of the Poor in Indonesia, 1999-2008.

The less-educational farmers lead to the awfully small income of the workers and eventually reduce the level of wealth in agricultural sector. Farmers also find it difficult to get access to obtain the materials and the market. This condition is exactly what makes poverty gap in Indonesia so high. This is irony, because agriculture is actually one that plays a big role in the development of a country. Agriculture sector in Indonesia has a role in:

1) Boosting economic growth

2) Providing job opportunity for the majority of labor force

3) Maintaining food security

4) Raw material producer for industrial sector

5) Rural development

\section{THE CHARACTERISTICS OF AgricUltURAL COMMODITIES IN INDONESIA}

Closely observed, the characteristic of Indonesia's agriculture is tropical. Given that the country placed in between two continents right at the equator, that can very much be understandable. Other than these natural factors, there are two others that also colors the country's nature of the agriculture. The first one is the shape of the nation that consists of thousands islands all over the place, and the second would be the topography that constains a lot of mountains [31].

Several important characteristics of commodities will be elaborated further in the following [32]:

1) Seasonal, agricultural product created through biological process that entirely depends on the climate and the nature that naturally makes the output volume to fluctuate a lot each season, especially in between harvest and famine season.

2) Easily damaged, usually the agricultural product is on the fresh state and ready to go on sale right afterwards, and to be under further making process. If the product is not consumed immediately or processed right away, the volume and the quality would drop over the time. This results to a decline economic value in agriculture, or even loses it all and be the biggest disadvantages for farmers.

3) Varieties of the commodities, the volume and the quality of agricultural products are very varied over the time and from each place to another, and from one production center to another with genetical and environment factor. Reaching a certain level of technology understanding would also determine the varieties of the product as in volume and quality in several places and in different time. This characteristic determines the amount of transaction costs that include information cost, negotiation cost, and contract securement. The bigger the varieties of the volume and quality of the products, the more complicated the transaction process would be. This also leads for bigger transaction cost.

4) Low price transmission, agricultural product possesses low transmission price elasticity and even sometimes point and the same direction. The rise in the consumer price does not immediately mean that there would be a rise in the producer price too. But on the other side, oppositely, a decline in consumer price would transmitted faster to producer price. Bottom line, farmers are placed on the weak side at the end of the day.

5) Monopsonistic market structure, it is common for the agricultural product to experience a monopsonistic market structure. Farmers usually be the weak one when it comes to facing the power of the consumers, that consisted of middlemen and huge group of traders that hold the power the control the market price.

Judging from the characteristics of the agricultural commodities proves that agricultural commodities are very susceptible to competition. So, farmers often face a trade-off condition. If not sold, the product will be damaged but if sold at a low price. So, most of farmers have low bargaining position.

By looking at the characteristics and conditions of agriculture in Indonesia, institutional food is the most important component in the basic formulation of food policy and agricultural development to achieve the welfare of the country [33]. Some existing policies in Indonesia in regulating agricultural sector, namely:

1) Pricing policies, institutions that regulate the price is a parastatal (Bulog) whose job is to buy and hold and products from farmers during the harvest season and market operations difficult when there is a commodity in the market. However, the dominance of political interests in the pricing policy appears to be greater than the efficiency and rationality of economic policies that rely on the proper allocation of resources [33].

2) Trade System Policy, trading system aspect of this still 
leaves the farm for the distortion due to inefficiencies caused by market and a different of actors behavior, especially the middleman. Besaide of that, the marketing aspect is also associated with the production aspect. Whereas in the context of agricultural production, the nature of which is striking in the production and marketing is a high seasonal levels.

\section{WHY INDONESIA JUST CAN'T DO IT}

The previous sections already discussed about the reality happened in Indonesia. How the agricultural sector works and the characteristics of the country, which lead to the next question: why Indonesia can not practice the fair trade like any other country does? This section will further explore what reason stands behind the lack of fair trade practice in Indonesia, which divided into two parts: internal factor and external factor.

\section{A. Internal Factor}

\section{1) Asymmetric information}

Information access decides whether farmers would stand in the upper hand in the business or not. Government of Indonesia already prepared institutions in favor of farmers to enhance their welfare (Gapoktan or Gabungan Kelompok Tani). Farmers that want to get assistance from the country needs to join the organization. There are plenty of things to be learned from such group, including management, organizational skill, technology, and any other information farmers need to get their hands to. However, despite the existence of the groups, there is a lot of information failed to land on farmers' ears [34].

\section{2) Underaged workers}

One of the standardization aspects of fair trade is about the fairness of the labour. Particularly, agriculture has been Indonesia's dominant economic sector and currently employing $40 \%$ of the labor force. Underaged workers are still common found in Indonesia, and some producers find it hard to keep up with the level of fair trade rules because of this factor. Labour, while it's a serious consideration factor of whether or not a business can be certified by Fair Trade Organization, is still hard to be applied as required in Indonesia [35], [36].

\section{B. External Factor}

\section{1) Middleman problem}

Even from 1989, one of Indonesia supply problems is the chain distributor. The problems now and back then are not all similar, as the country already enhanced some parts such as infrastructure, communication access, technology, and input suppliers, but some still remains the same. Fixing merely the infrastructure does not magically sweep away the distribution difficulties. Middleman comes between the producer and the consumer in a way that has not be underestimated [37], [38].

Middleman plays an important economic role in Indonesia. The fact that BULOG or Badan Urusan Logistik (Logistic Management Board) does not currently work as the intial goal of the institution, the hole of a middleman becomes a competition among non government distributors. Conventional trade theory always focused at the cost whenever discussing about business in agriculture, but intermediary's role in the world often to be overlooked. Producer can not directly sell to the consumers, thus has to sell to intermediaries instead. In a word, the reason cited as an "entrepreneurial ability" [39], [40].

\section{2) Public awareness}

Consumers that buy organic food expecting better taste, quality, safer and healthier products. Fair trade certification guarantees these kinds of aspects almost immediately, so it's given that fair trade and consumer's interest are positively related. Other than that, values are a big thing in Indonesia's cultural behavior, and based from fair trade initial purposes to create fairness not only for consumers but also for producers, especially small-scale ones, has anything to do with social value [41], [42].

Unfortunately, fair trade is still not immensely known and popular yet in Indonesia. This can be indicated by the fact that this country still not being added to Fair Trade Organization list of countries. Indonesia still has not fully embraced the idea yet and still has not built any fair trade organization, legally.

\section{3) Consumer's willingness to pay (WTP)}

Related to public awareness, Indonesian consumer's willingness to pay is heavily depends on age and income, while income inequality is a big issue because the range is still wide. The common mindset of consumers is to pay less, get more. Weekly market, night market, or events when consumers can buy goods with less prices are very popular in Indonesia [43], [44].

\section{HOW TO IMPROVE FAIR TRADE INTO A BETTER SYSTEM IN INDONESIA}

The last part of the paper comes as a recommendation of how to do the fair trade in the right way in Indonesia. Coming across the barriers of fair trade implication in the country, there are 3 parts of the suggestion, which are divided to consumer, producer, and the government's side.

\section{A. Consumer \\ 1) Raising awareness}

In order to raise awareness of fair trade to Indonesian consumers, there are three things that can be done. First, media is a perfect weapon to embed information or images to people's mind. Using television or internet to put up interesting ads would result in a better acknowledgement for consumers in all age. Second, the clever way to inform young generation is by holding events with a fair trade as a theme. For example, using fair trade as a theme in paper competition. The third way would be socialization through events held specially by fair trade organizations.

\section{2) Taking participation}

Given that Indonesian consumers still not up yet to fair trade idea, which is sharing fairness to all sides during economic transactions, dragging people into participation is very much required. Incentives would be a good start to gain consumers' interest to buy fair trade products. Simple example would be that if consumer willing to buying fair trade products for some number of amount, they would be given one extra product, in which they can choose the bonus 
on their own.

\section{B. Producer}

\section{1) Information access}

Asymmetric information, though can not be avoided in the full extent, it still can be lessened by a very careful and selective process in choosing a Gapoktan Leader. The success of every Gapoktan depends almost entirely on the leader, therefore in order to maximize the usefulness of the group, it must be monitored very carefully during the selection.

\section{2) Quality improvement}

Not only grasping the idea of fair trade and get fair prices, the quality of the product must be enhanced too. As labor is one of the things Indonesian producers are still lacking at, the monitoring and quality improvement to become more professional in the business has not to be overlooked for.

\section{Government}

\section{1) Supply chain}

Improving supply chain and rearranging the distribution system would be the long-lasting homework for the government of Indonesia. It is not enough only to build institution in which the main role of it is to distribute goods from producers to consumers, and to make sure the country has sufficient supply, but the government must do whatever it takes to make the institution works.

\section{2) Cost-reducing policy}

Since cost is the final obstacle for all agricultural producers, the government must avoid policy that absorbs cost. By cost it's not only money but also time and opportunity cost. Reducing the birocracy's complexities would be a giant leap to reduce the cost, and other example would be eliminating barriers for producers to expand the business.

\section{3) Education}

In developing countries, people that are not up to average education level are still common. By average, it means finishing a high school diploma, as it is a must in Indonesia. It's very important for farmers to understand their rights and responsibility concerning fair trade, and the first step of it is getting a proper education. The government should make education much easier for farmers to access. One way to do it is to lower or even release them from all fees.

\section{CONCLUSION}

Fair trade, while it is a common form of business in the world, is still unknown in some parts of the world. The success of the system heavily depends on the characteristics of the country. The best strategies differ for each need, and fit different kind of nature. Naturally, the problem is not the same for all, for example in Indonesia. The awareness is still not that high compared to other developing countries, and the country still has not listed at Fair Trade Organization yet. Other crucial reason would be middleman problem. It dominates the distribution system of the agriculture sector in Indonesia.

These problems would be solved by fully improving the work of institutions and maximizing the potentials of the human resources. Education is the best step to reach that goal, both for the consumers and the producers. To make the farmers understand their role in the game can be done by getting them proper education, and to 'educate' consumers about the world of fair trade can be done through various kinds of promotion, such as using the media as the ultimate weapon and encouraging the students to learn more through paper competition held with fair trade as the main theme.

\section{REFERENCES}

[1] M.-C. Renard, "Fair trade: quality, market, and conventions," Journal of Rural Studies, vol. 18, pp. 87-96, 2003.

[2] M.-C. Renard, "Quality certification, regulation, and power in fair trade," Journal of Rural Studies, vol. 21, pp. 419-431, 2005.

[3] M. Adams and J. Raisborough, "Encountering the fairtrade farmer: Solidarity, stereotypes, and the self-control ethos," Papers on Social Representations, vol. 20, pp. 8.1-8.21, 2011.

[4] M. K. Goodman, "Reading fair trade: Political ecological imaginary and the moral economy of fair trade foods," Political Geography, vol. 23, pp. 891-915, 2004.

[5] A. Marston, "Justice for all? Material and semiotic impacts of fair trade craft certification," Geoforum, vol. 44, pp. 162-169, 2012.

[6] A. Herman, "Connecting the complex lived worlds of Fairtrade," Journal of Environmental Policy and Planning, vol. 12, no. 4, pp. 405-422, 2010.

[7] L. Becchetti and M. Constantino, "The effects of fair trade on affiliated producers: An impact analysis on Kenyan farmers," World Development, vol. 36, no. 5, 2008.

[8] S. D. Elder et al., "Is fairtrade certification greening agricultural practices? An analysis of fairtrade environmental standards in rwanda,' Journal of Rural Studies, vol. 32, pp. 264-274, 2013.

[9] E. J. Arnould et al., "Does fair trade deliver its core value proposition? Effects on income, educational attainment, and health in three countries," Journal of Public Policy and Marketing, vol. 28, no. 2, 2009.

[10] M. P. Todaro, Ekonomi Pembangunan, Jakarta: Erlangga, 2002.

[11] WFTO, Annual Report, 2009.

[12] Fair Trade Advocacy Newsletter. (2005). [Online]. p. 4. Available: http://www.bafts.org.uk/BAFTS_files/FTAN_April_05.pdf

[13] European Fair Trade Assosiation, Fair Trade Year Book: Towards 2000, Belgium: Druk in De Weer, 1998.

[14] R. Belling, "Fair Trade in the North," in Proc. Workshop: Reregulating the Global Economy through Fair Trade: Setting a Research Agenda, Colorado State University, 2000.

[15] M. Boonman et al., "A Success story for producers and consumers," Fair Trade Facts and Figure, 2010.

[16] L. T. Raynolds, D. Murray, and A. Heller, "Regulating sustainability in the coffee sector: A comparative analysis of third-party environmental and social certification initiatives," Agriculture and Human Values, vol. 24, no. 2, pp. 147-163, 2007.

[17] L. Ronchi, "The impact of fair trade on producers and their organisation: A case study with coocafe in Costa Rica," Prus Working paper No.11, 2002

[18] B. Christopher, "Confronting the coffee crisis: Can fair trade, organic, and specialty coffees reduce small-scale farmer vulnerability in Northern Nicaragua?" World Development, vol. 33, no. 3, pp. 497511,2005

[19] Fair Trade Labelling Organization International. [Online]. Available: http://www. Fair-trade.net

[20] P. Parvathi and H. Waibel, "Fair trade and organic agriculture in developing countries: A review," Journal of International Food and Agribusiness Marketing, vol. 25, no. 4, pp. 311-323, 2013.

[21] J. G. Weber, "How Much more do growers receive for fair tradeorganic coffee?" Food Policy, vol. 36, pp. 678-685, 2011.

[22] C. D. Gingrich and J. K. Emily, "Does fair trade fulfill the claims of its proponents? Measuring the global impact of fair trade on participating coffee farmers," Journal of Cooperatives, vol. 26, pp 17-39, 2012.

[23] G. Balineau, "Disentangling the effects of fair trade on the quality of malian cotton," World Development, vol. 4, pp. 241-255, 2012.

[24] D. L. Murray et al., "The future of fair trade coffee: Dilemmas facing Latin America's small-scale producers," Development in Practice, vol. 16, no. 2, 2006.

[25] O. Kirezli and Z. K. Kuscu, "Exploring Fair Trade Attitude and Fair Trade Behavior of Turkish Consumers," Procedia Social and Behavioral Sciences, vol. 58, pp. 1316-1325, 2012. 
[26] G. A. Amalia and R. Nigh, "SMALLHOLDER participation and certification of organic farm products in mexico," Journal of Rural Studies, vol. 21, pp. 449-460, 2005.

[27] R. Loraine, "Fairtrade and Market failures in agricultural commodity markets," World Bank Policy Research Working Paper. 4011, 2006.

[28] Badan Pusat Statistik, Indonesia Statistic, 2013.

[29] WFTO, WFTO Statistic, 2013.

[30] A. Suryahadi and G. Hadiwidjaja, The Role of Agriculture in Poverty Reduction in Indonesia, Jakarta: Semeru Research Institute, 2011.

[31] Mubyarto, Peluang Bekerja dan Berusaha di Pedesaan, Yogyakarta: BPFE untuk P3PK UGM, 1994.

[32] A. K. Zakaria, "Program Pengembangan Agribisnis Kedelai Dalam Peningkatan Produksi dan Pendapatan Petani," Journal Litbang Pertanian, vol. 29, no. 4, 2010.

[33] B. Arifin, Diagnosis Ekonomi Politik Pangan dan Pertanian. (The Political Economy of Food and Agriculture), Jakarta: Raja Grafindo Persada (Rajawali Pers), 2005.

[34] S. Nuryanti and K. S. S. Dewa, "Roles of farmers' groups in agricultural technology adoption," Forum Penelitian Agro Ekonomi, vol. 29, no. 2, 2011.

[35] S. Pramono, "Perjuangan menuju fair trade: Pengalaman APIKRI Dalam Memediatori Pengrajin Lokal Dan D'Best Furniture Dalam Mensiasati Eco-Labeling," Journal Ilmu Politik Hubungan Internasional, vol. 12, no. 2, 2012.

[36] International Markets Bureau, "The Indonesian consumer behaviour, attitudes, and perceptions towards food products," Agriculture and Agri-Food Canada, 2011.

[37] K. Toshihiko and Y. Hayami, "Farmers and middlemen in transmigration area in Indonesia," Bulletin of Indonesian Economic Studies, vol. 25, no. 3, pp. 73-97, 2006.

[38] U. Parhusip, "Supply and demand analysis of rice in Indonesia," pp. 1950-1972, 1976

[39] E. Bonacich, "A theory of middleman minorities," American Sociological Review, vol. 38, pp. 583-594, 1973.

[40] B. Pranab et al., Middlemen Margins and Globalization, 2011.

[41] S. Budi et al., "Indonesian consumer's attitudes towards organic products," in Proc. $8^{\text {th }}$ Asian Business Research Conference, Bangkok, Thailand, 2013.

[42] S. O. Sihombing, "Identifying changing in indonesian values and its impact to indonesian consumer behavior," Journal Language, Culture, and Society, vol. 36, pp. 101-109, 2013

[43] R. P. Yusuf, "Consumer willingness to pay for poultry products from biosecure farms in Bali," in Proc. 55 ${ }^{\text {th }}$ National Conference of the Australian Agricultural and Resource Economics Society, 2011.

[44] L. Andrew and P. van der Eng, "Inequality in Indonesia: What can we learn from top Incomes?" Journal of Public Economics, vol. 93, pp 209-212, 2008.

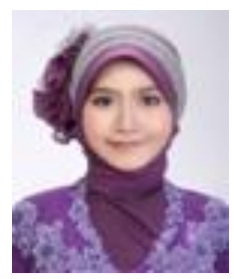

Ermita Yusida is originally from Blitar, Indonesia. She finished her bachelor degree in 2012 at the University of Brawijaya, Malang, Indonesia in Faculty of Economics and Business (a major in department of economics). Then, she continued her master degree with the double degree program in University of Brawijaya and National Pingtung University of Science and Technology (NPUST) in Taiwan. She finished her program in Indonesia for a year, and then she continuing her program in NPUST for a year. Currently, she is taking Department of Agribusiness Management in NPUST. Her first journal is entitled "The Impact of Double Squeeze Phenomenon on east Java Small Medium Enterprise Sustainability after ASEAN China Free Trade Agreement (ACFTA) Implementation".

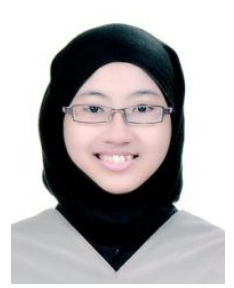

Degree program.
Juwita P. R. Suwondo was born at Malang, Indonesia on August 7, 1990. She completed her bachelor degree at University of Brawijaya, Malang at June, 2012. She majored in banking and currently taking Islamic economics major at the same university in master degree in the first year, while the remaining year will be spent in Graduate Institute of Finance National Pingtung University of Science and Technology at Pingtung, Taiwan, as part of Double 